\title{
Modulation of sexual behavior of Morada Nova ewe by the season of the year in a semiarid equatorial environment
}

\author{
Luana de Fátima Damasceno dos Santos ${ }^{\circledR} \mid$ Edilson Paes Saraiva ${ }^{b}$ (iD $\mid$ Dermeval Araújo Furtado | \\ Edgard Cavalcanti Pimenta Filho | Tarsys Noan Silva Veríssimo | Natanael Pereira de Arruda | \\ Leonardo Santos Silva' Severino Guilherme Caetano Gonçalves dos Santos ${ }^{\circledR}$ Geni Caetano Xavier \\ Neta ${ }^{\text {iD }}$ | Larissa Kellen da Cunha Morais | José Danrley Cavalcante dos Santos
}

${ }^{a}$ Department of Agriculture and Agroecology, State University of Paraíba, Lagoa Seca, Paraiba, Brazil.


Paraiba, Brazil.

'Departament de Agricultural Engineering, Federal University of Campina Grande, Campina Grande 58428-830, Paraiba, Brazil.

Departament of Animal Sciences, Federal University of Paraiba, CCA, Areia 58397-000, Paraiba, Brazil.

eNational institute of Semiarid (INSA), Campina Grande 58434-700, Paraiba, Brazil.

*Corresponding author: edilson@cca.ufpb.br

\begin{abstract}
The objective was to evaluate the effect of the season on the sexual behavior patterns adopted by Morada Nova sheep in the Brazilian semiarid region. A total of 55 and 59 female sheep were used in the rainy and dry seasons, respectively, attended by four males of the same breed in rotation. The females identified in oestrus were released in a pasture, together with the breeder of the day for each season, and aspects of sexual behavior were measured for an uninterrupted period of 11 hours/day. Assuming a negative binomial distribution, the behavioral frequencies were subjected to deviation analysis and compared using the chi-square. Heading in the male was observed more frequently during the rainy season (0.12) and shifts with higher temperatures; the turn of the head in relation to the man was observed more frequently during the dry season (2.49). The interactions between seasons and shifts significantly affected the following behaviors: sniffing the male, sniffing the male's urogenital region, wagging the tail, lifting the tail, and urinating. Behavioral variables were influenced by the season. Morada Nova sheep reduce their water intake and grazing time to engage more efficiently in reproductive activities, thus demonstrating an ability to adapt to the Caatinga.
\end{abstract}

Keywords: environmental conditions, reproductive ethology, seasonality sheep

\section{Introduction}

In semiarid regions, environmental conditions can determine the efficiency of sheep production systems. In these regions, high air temperatures, high levels of direct solar radiation, and lack of rainfall seasonality can modify animal behavior during the breeding season (Finch 1984; Santos et al 2015). Thus, one of the main limitations for animal reproduction is stress (for example, thermal, nutritional, and water stress) (Sejian et al 2012). In this study, the authors observed that the increase in cortisol under thermal, nutritional, or locomotion conditions stress affects the preovulatory increase in estradiol, leading to negative consequences. According to Santos et al (2015), thermal stress modified the sexual behavior of Morava Nova sheep. Changes in the seasonality of sheep were mainly influenced by the quality and availability of food (Villarroel and Fernandes 2000; Martin et al 2002), which is favorable during the rainy season.
The sexual behavior of females in estrus can be assessed by characteristics of proceptivity, attractiveness, and receptivity in response to the stimuli provided by the male (Beach 1976). However, it has been reported that these behaviors can be influenced by genetic, nutritional, environmental factors (Pacheco and Quirino 2010), sexual experience, in addition to hormonal and social factors (Stellflug and Lewis 2007). Morada Nova sheep were shown to be advantageous due to their adaptability to arid and semiarid environments, productive and reproductive efficiency (Santos et al 2015), in addition to the high rate of prolificacy and good maternal capacity (Fonsêca et al 2016), contributing for the use of the genotype in semiarid regions of Brazil, specifically in situations of large circadian variations in air temperature and in the availability of water and food.

Under tropical conditions, studies that provide a detailed assessment of behavioral patterns in the sheepmating period should be expanded, especially those related to reproductive performance when water scarcity is combined with few food resources available. In addition, 
most studies highlight investigations with sheep. The effect of the season on the sexual behavior of Targhee sheep has been reported, noting that seasonal differences influence the sexual activity of males of this species (Pepelko and Clegg 1995). In contrast, studies have investigated the effect of the Pelibuey, Blackbelly, Dorper, and Katahdin breeds and age (young and adult) on the reproductive behavior of sheep in tropical conditions (Aké-Villanueva et al 2019).

Experimentally analyzing the reproductive behavioral repertoire of sheep subjected to these environmental conditions (rainy season and dry season) can help us understand how these animals deviate their energies to prioritize reproduction at a specific time of the year.

The objective was to investigate the effect of the dry and rainy seasons on the patterns of sexual behavior adopted by Morada Nova ewes in the Brazilian semiarid region.

\section{Materials and Methods}

\subsection{Experimental area and climate}

The study was approved by the Ethics and Animal Use Committee of the Federal University of Paraíba. The experiment was conducted at the Research Unit in Small Ruminants, located in the municipality of São João do Cariri, Paraíba, Brazil ( $07^{\circ} 23^{\prime} 27^{\prime \prime}$ South and $36^{\circ} 31^{\prime} 58^{\prime \prime}$ West), at an altitude of $458 \mathrm{~m}$. The region's predominant climate is Bsh (hot semiarid), according to the Köppen classification (1936). The typical vegetation is classified as hyperxerophytic Caatinga distributed at low depths and in very stony soil.

\subsection{Animals, management and experimental diet}

During the rainy season (June $=17$ days), 55 Morada Nova ewes were used, 24 nulliparous and 31 multiparous. In the dry season (January = 19 days), 59 ewes were used, 32 nulliparous and 27 multiparous. Previously, all women received numerical identification with permanent tincture in the abdominal region. Four Morada Nova rams were used during the two seasons for three days.

The females were kept on a semi-extensive diet in both seasons. At 5:00 am, females in possible estrus were identified; a male was taken to the females' stall by a rope and left with the female for 15 minutes. After oestrus detection - at 06:00 am - all females were released in an area of 2.5 ha in the Caatinga for behavioral assessments, followed by the release of the breeder previously selected for the day.

Throughout the day, females who presented estrus were also marked, and their behavior was recorded. Upon returning from the field at 5:00 pm, they received $300 \mathrm{~g}$ of feed containing $17 \%$ crude protein (CP) and 2.8 Mcal formulated according to the NRC (1985). Supplementary forage consisting of sorghum, Tifton hay, and forage palm was provided during the dry season. The sheep also received mineral supplementation and water ad libitum.

\subsection{Environmental variables}

The climatic variables were recorded using the digital thermo-hygrometer (Highmed - Model HM02) positioned at the location of the experiment at a point equivalent to the height of the animals $( \pm 0.8 \mathrm{~m})$. In an interval of 2 hours - from 5:00 am to 5:00 pm - data on ambient temperature (AT: ${ }^{\circ} \mathrm{C}$; range: - 50 to $70^{\circ} \mathrm{C}$; accuracy $\left.\pm 1{ }^{\circ} \mathrm{C}\right)$, relative humidity $(\mathrm{RH}: \%$; range: 0$)$ were collected 99\%; accuracy $\pm 5 \%$ ) and temperature of the black globe using plastic sphere $(5 \mathrm{~mm}$ thick and $0.15 \mathrm{~m}$ in diameter), painted black and with dry bulb thermometer (range: $-10^{\circ} \mathrm{C}$ to $+60^{\circ} \mathrm{C}$; accuracy $\pm 1{ }^{\circ} \mathrm{C}$ ). From the black globe, the black globe temperature and humidity index (BGTHI) was calculated according to the formula described by Buffington et al (1981) adapted by Barbosa and Silva (1995):

$$
\mathrm{BGTHI}=\mathrm{BGT}+0.36 *(\mathrm{DPT})+41.5
$$

where: BGT is the black globe temperature $\left({ }^{\circ} \mathrm{C}\right)$, and DPT is the dew-point temperature $\left({ }^{\circ} \mathrm{C}\right)$. Readings were taken on the same days as the behavioral tests, at 2-hour intervals.

Five shifts were defined: three in the morning (shift 1 : from 6:00 am to 7:00 am; shift 2: from 7:01 am to 9:00 am; shift 3: from 9:01 am to 11:00 am) and two in the afternoon shift 4: from 11:01 am to 3:00 pm and shift 5: from 3:01 pm at 17:00). Shifts were grouped to separate periods with higher temperatures from those with milder temperatures (Table 1).

Table 1 Mean environmental temperature (ET) during the different shifts, mean relative humidity $(\mathrm{RH})$, and mean black globe temperature and humidity index (BGTHI) as a function of the season.

\begin{tabular}{lcc}
\hline \multirow{2}{*}{ Shifts } & \multicolumn{2}{c}{ Seasons } \\
\cline { 2 - 3 } & \multicolumn{2}{c}{ Ambient temperature $\left({ }^{\circ} \mathrm{C}\right)$} \\
\cline { 2 - 3 } & Rainy & Dry \\
\hline Shift 1 & 22.5 & 24.4 \\
Shift 2 & 26.3 & 27.4 \\
Shift 3 & 29.9 & 30.4 \\
Shift 4 & 31.4 & 32.7 \\
Shift 5 & 29.6 & 32.6 \\
\hline RH (\%) & 60.2 & 46.1 \\
\hline BGTHI & 76.5 & 78.9 \\
\hline
\end{tabular}

${ }^{1}$ Shift 1: 6:00 to 7:00 am; shift 2: 7:01 to 9:00 am; shift 3: 9:01 to 11:00 am; shift 4: 11:01 am to $3: 00 \mathrm{pm}$ and shift $5: 3: 01 \mathrm{pm}$ to $17: 00 \mathrm{pm}$.

\subsection{Behavioral observations}

Trained observers recorded each sheep's time and specific behavior in the oestrus (Table 2), using ethogram and digital timer resources. The behaviors were recorded continuously from 6:00 am to 5:00 pm, totaling 11 hours daily, using the focal animal sampling method. Water intake frequencies (WI) were also counted - in which the female's frequency of ingesting water directly from the drinking fountain or other water source and grazing activity (GA) females grazing.

\subsection{Statistical analysis}

Assuming a negative binomial distribution, the behavioral data were submitted to Deviance analysis 
(generalized linear model), using the GLIMMIX procedure and compared using the chi-square test. The climatic variables were subjected to analysis of variance and the means compared by the Tukey test. The analyzes were performed using the $\mathrm{SAS}^{\circledR}$ (Statistical Analysis System, 9.3), adopting a significance of $5 \%$ probability $(P<0.05)$.

Table 2 Description of sexual activities performed by the ewe.

\begin{tabular}{|c|c|}
\hline $\begin{array}{l}\text { Behavior } \\
\text { (Abbreviation) }\end{array}$ & Description \\
\hline SURF & Sniffing the urogenital region of another female \\
\hline SURM & Sniffing the urogenital region of the male \\
\hline SM & $\begin{array}{l}\text { Sniffing any region of a male other than the } \\
\text { urogenital region }\end{array}$ \\
\hline ST & Swinging the tail in the presence of the male \\
\hline LT & Lifting the tail in the presence of the male \\
\hline TH & Turning the head in search of the male \\
\hline URI & Urination by the female \\
\hline FR & Flehmen reflex by the female \\
\hline $\mathrm{HB}$ & Headbutting the male \\
\hline VOC & $\begin{array}{l}\text { Vocalization at low or high intensity towards } \\
\text { the male }\end{array}$ \\
\hline CON & Contact with the male \\
\hline $\mathrm{MCIR}$ & Male and female moving in circles \\
\hline SEXD & $\begin{array}{l}\text { Sexual disinterest on the part of the female, } \\
\text { fleeing the mount }\end{array}$ \\
\hline NASA & No apparent sexual activity \\
\hline
\end{tabular}

\section{Results}

Among the sexual behaviors, it was observed that the frequency in which the behavior of turning the head in search of the male (TH) and hitting the head on the male (HB) occurred significantly $(P<0.05)$ per season; more specifically, carried out constantly during the rainy season (Table 3$)$. On the other hand, females' water consumption (WI) and grazing (GRA) decreased during the rainy season. The sexual behaviors consisted of sniffing another female's urogenital region (SURF), coming into contact with the male (CON), moving in circles (MCIR), performing the Flehmen reflex (FR), and vocalizing (VOC) were frequently performed during the rainy season. While animals that did not exhibit apparent sexual activity (NASA) and sexual disinterest (SEXD) showed a higher occurrence of these behaviors during the same season.

Significant differences $(P<0.05)$ in the frequency with which the females turned their heads in search of the male sex (TH) were observed per shift; more specifically, this behavior was exhibited to a lesser extent during the subsequent shifts than during the initial shifts (Table 4).

Statistical analysis revealed a significant interaction ( $P$ $<0.05$ ) between the dry and rainy seasons, significantly affecting the following behaviors: sniffing the male (SM), sniffing the male's urogenital region (SURM), wagging the tail (ST), tail lift (LT) and urination (URI) (Table 5).

\section{Discussion}

As the study was carried out in a semiarid region with high temperatures and low relative humidity (Table 1 ), one of the hypotheses was that the sheep consumed more water during the dry season. However, this behavior was not observed, illustrating the adaptive value of animals of this genotype to these environmental conditions and prioritizing the perpetuation of species through reproduction. According to Roll et al (2006), animals adapt to the environment in which they live, perpetuating the species. Thus, through a series of sexual events and stimuli, one of the main objectives of reproduction is to guarantee fertilization, the perpetuation of the species, and, consequently, the survival of their young (Pacheco and Quirino 2010).

Table 3 Frequencies with which sexual behaviors were performed by females during breeding by season.

\begin{tabular}{lllc}
\hline & & \multicolumn{2}{c}{ Season } \\
\cline { 2 - 4 } Behaviors & & & \\
WI & Rainy & Dry & 0.12 \\
GRA & 0.02 & 0.00 & 0.00 \\
SURF & 0.54 & 0.02 & 0.00 \\
TH & 0.04 & 0.00 & 43.18 \\
HB & $1.52^{\mathrm{b}}$ & $2.56^{\mathrm{a}}$ & 6.16 \\
FR & $0.12^{\mathrm{a}}$ & $0.05^{\mathrm{b}}$ & 0.01 \\
VOC & 0.04 & 0.03 & 2.17 \\
NASA & 0.02 & 0.00 & 0.00 \\
CON & 0.34 & 0.01 & 0.00 \\
MCIR & 0.10 & 0.05 & 3.17 \\
SEXD & 0.06 & 0.04 & 0.00
\end{tabular}

Means followed by different letters in the row differ by chi-square test; ${ }^{1}$ Water intake (WI), grazing (GRA), smelling the urogenital region of another female (SURF), turning the head in search of the male (TH), headbutting the male (HB), Flehmen reflex (FR), vocalization (VOC), no apparent sexual activity (NASA), contact with the male (CON), moving in circles (MCIR) and sexual disinterest (SEXD). 
Social interactions in ruminants occur due to the gregarious life habits of these animals. However, these interactions can be compromised when there are competition resources and sexual partners. This competition occurs through aggressions between animals due to the establishment of dominance (Costa e Silva 2007). The behavior of hitting the head on the male corroborates this hypothesis since the butt is related to the social hierarchy among animals. When a male shows interest in an oestrus female, other oestrus females interfere with the procession by hitting the male on the head. As more grazing is available during the rainy season, the animals stay together for long periods; for this reason, the behavior of hitting the male head was accentuated during the rainy season. In studies with sheep Morada Nova, Almeida (2016) found that the dominance of sheep of this breed is more noticeable when resources are limited. However, further studies are needed to investigate this domain about sexual partners. Côté and
Festa-Bianchet (2001), investigating the dominance of mountain goats in Caw Ridge, showed that goats considered dominant had higher reproductive success in producing a child than submissive females.

The reflex behaviors of Flehmen, vocalization, contact with the male, movement in circles, no apparent sexual activity, and sexual disinterest were observed less frequently during the rainy season. During the dry season, probably due to thermal stress; consequently, behaviors aimed at promoting sexual interaction between the sexes were limited. Sejian et al (2012) observed multiple nutritional, thermal, and locomotion stresses and a concomitant reduction in plasma estradiol levels in Bharat Merino sheep, native to India. According to Pereira (2005), hormones related to stress can influence the sexual function of animals, inhibiting the secretion of $\mathrm{GnRH}$, which consequently will decrease the release of $\mathrm{LH}$ and FSH, promoting a decrease in reproductive function as well as in sexual interaction.

Table 4 The frequency with which sexual behaviors were performed by female sheep during breeding by shift.

\begin{tabular}{|c|c|c|c|c|c|c|}
\hline \multirow[b]{2}{*}{ Behaviors ${ }^{2}$} & \multicolumn{5}{|c|}{ Shifts $^{1}$} & \multirow[b]{2}{*}{ Chi-square } \\
\hline & 1 & 2 & 3 & 4 & 5 & \\
\hline WI & 0.00 & 0.00 & 0.00 & 0.02 & 0.02 & 0.23 \\
\hline GRA & 0.04 & 0.19 & 0.43 & 0.26 & 0.28 & 5.60 \\
\hline SURF & 0.01 & 0.01 & 0.05 & 0.02 & 0.03 & 1.57 \\
\hline TH & $2.01 \mathrm{~b}$ & $2.23^{\mathrm{ab}}$ & $2.22^{\mathrm{ab}}$ & $1.80^{c}$ & $2.49^{a}$ & 9.76 \\
\hline FR & 0.02 & 0.05 & 0.04 & 0.02 & 0.05 & 3.90 \\
\hline $\mathrm{HB}$ & 0.06 & 0.08 & 0.11 & 0.05 & 0.11 & 4.86 \\
\hline VOC & 0.00 & 0.02 & 0.01 & 0.00 & 0.10 & 0.81 \\
\hline NASA & 0.09 & 0.12 & 0.18 & 0.17 & 0.21 & 1.48 \\
\hline CON & 0.09 & 0.08 & 0.10 & 0.05 & 0.05 & 1.97 \\
\hline $\mathrm{MCIR}$ & 0.02 & 0.04 & 0.05 & 0.05 & 0.10 & 2.37 \\
\hline SEXD & 0.01 & 0.10 & 0.11 & 0.08 & 0.04 & 1.75 \\
\hline
\end{tabular}

Means followed by different letters in the row differ by chi-square test; Water intake (WI), grazing (GRA), smelling the urogenital region of another female (SURF), turning the head in search of the male (TH), headbutting the male (HB), Flehmen reflex (FR), vocalization (VOC), no apparent sexual activity (NASA), contact with the male (CON), moving in circles (MCIR) and sexual disinterest (SEXD); ${ }^{1}$ Shift 1: 6:00 to 7:00 am; Shift 2: 7:01 to 9:00 am; Shift 3: 9:01 to 11:00 am; Shift 4: 11:00 am to 15:00 pm and Shift 5: 15:01 to 17:00 pm.

Table 5 The frequency with which behaviors were performed by females during breeding in the rainy and dry seasons during the morning and afternoon shifts.

\begin{tabular}{|c|c|c|c|c|c|}
\hline \multicolumn{6}{|c|}{ Rainy Season } \\
\hline Shifts ${ }^{1}$ & SM & SURM & ST & LT & URI \\
\hline 1 & $0.53^{\mathrm{Aa}}$ & $0.51^{\mathrm{Aa}}$ & $1.01^{\mathrm{Bb}}$ & $0.05^{\mathrm{Bb}}$ & $0.10^{\mathrm{Ba}}$ \\
\hline 2 & $0.52^{\mathrm{Aa}}$ & $0.75^{\mathrm{Aa}}$ & $2.90^{\mathrm{Ab}}$ & $0.29 \mathrm{ABa}$ & 0.09 ва \\
\hline 3 & $0.43^{\mathrm{Aa}}$ & $0.78^{\mathrm{Aa}}$ & $2.03^{A b}$ & $0.45^{\mathrm{Aa}}$ & $0.10^{\mathrm{Ba}}$ \\
\hline 4 & $0.51^{\mathrm{Aa}}$ & $0.36^{A a}$ & $1.09^{\mathrm{Bb}}$ & $0.46^{\mathrm{Aa}}$ & $0.16^{\mathrm{ABa}}$ \\
\hline 5 & $0.92^{\mathrm{Aa}}$ & $0.42^{A b}$ & $1.72^{\mathrm{ABb}}$ & $0.77^{\text {Aа }}$ & 0.39 Аа \\
\hline \multicolumn{6}{|c|}{ Dry Season } \\
\hline Shifts $^{1}$ & SM & SURM & ST & $\mathrm{LT}$ & URI \\
\hline 1 & $0.14^{\mathrm{Bb}}$ & $0.47^{\mathrm{Ba}}$ & 4.09Aba & $0.32^{\mathrm{Aa}}$ & $0.03^{\mathrm{Ba}}$ \\
\hline 2 & $0.22^{\mathrm{ABb}}$ & $0.44^{\mathrm{Ba}}$ & $4.91^{\mathrm{Aba}}$ & $0.29 \mathrm{Aa}$ & $0.13^{\mathrm{ABa}}$ \\
\hline 3 & $0.36^{\mathrm{ABa}}$ & $0.30^{\mathrm{Bb}}$ & $4.83^{\mathrm{Aba}}$ & $0.18^{A b}$ & $0.18^{\mathrm{Aa}}$ \\
\hline 4 & $0.46^{\mathrm{Aa}}$ & $0.36^{\mathrm{Ba}}$ & $3.41^{\mathrm{Ba}}$ & $0.27^{\mathrm{Aa}}$ & $0.11^{\mathrm{ABa}}$ \\
\hline 5 & $0.14^{\mathrm{Bb}}$ & $1.35^{\mathrm{Aa}}$ & $5.52^{\mathrm{Aa}}$ & $0.15^{A b}$ & $0.15^{\mathrm{ABb}}$ \\
\hline
\end{tabular}

Means followed by different uppercase letters in the column and lowercase letters in the row are significantly different $(P<0.05)$ for the same parameter ${ }^{1}$ Shift 1: 6:00 to 7:00 am; Shift 2: 7:01 to 9:00 am; Shift 3: 9:01 to 11:00 am; Shift 4: 11:01 am to 15:00 pm and Shift 5: 15:01 to 17:00 pm. Sniffing the male (SM), sniffing the urogenital region of the male (SURM), swinging the tail (SW), lifting the tail (LT) and urination (URI). 
Sexual behaviors such as smelling another woman's urogenital region and the Flehmen reflex are commonly practiced by men after smelling freshly excreted urine; no studies have been conducted to examine this behavior in women. Concerning these behaviors, there was a decrease in the behavioral displays of females during the two seasons and in all shifts, probably because they do not frequently occur in females; the different temperatures during the different shifts did not seem to influence these behaviors. This can probably be related to the low level of sexual interaction between females in estrus and the externalization of sexual behavior only for the interest in the male breeder.

The behavior of the females turning their heads in search of the male was observed less frequently in shift 4, when the animals tended to group in shaded areas and, therefore, were physically closer to the breeder. This behavior of females turning their heads in search of the male was more externalized in turns 2, 3, and 5. During shifts 2 and 3 , a higher frequency of females turning heads in search of males coincided with more intense pastures by the breeder and the tendency of the male to move away from the females. While in turn 5, despite the clustering observed during the final shift, the animals tended to rest and ruminate. Throughout the group, the breeder courted females in estrus; in response, the female assumed a mating posture, leading to the female motor activity turning her head in search of the most frequent male. Llewelyn et al (1993) observed that $90 \%$ of estrous goats tend to look for the breeder, showing a behavior with visual communication between individuals (Gill 2008).

The lack of interest associated with the variables without apparent sexual activity and the lack of sexual interest probably suggest that the stimulus triggered by the ram was not strong enough to stimulate the females during the different shifts. This fact can be attributed to the testosterone concentrations in the male that decrease in places with high temperatures, causing a decrease in libido, as was observed in sheep (Gomes et al 1971; Saumand and Rouger 1972). Rosa and Bryant (2003) suggest that variations in temperature, relative humidity, and rainfall distribution in tropical and subtropical regions affect the reproductive characteristics of sheep.

In the Northeast of Brazil, particularly in the semiarid region, sheep undergo a natural selection over time, resulting in breeds with adaptability and good reproductive capacity. For this reason, most of the sexual behaviors exhibited by the Morada Nova sheep, including the behavior of hitting the male head, vocalizing, coming into contact with the male, and moving in circles, were not inhibited by temperature fluctuations during shifts studied.

Sheep use their sense of sight, hearing, smell, taste, and touch to interact with the environment (Gill 2008) and perceive the stimuli of sex hormones released by males (Rosa and Bryant 2002). These senses are considered indicators and/or mediators of the behavioral response; for example, the behaviors of sniffing the man and sniffing the urogenital region of the man, suggesting an important function of chemical communication through smell. The act of sniffing the male is associated with reproduction, as males have a more pronounced odor during the breeding period, due to the release of their pheromones into the environment, mainly through urine. The pheromones released by urine, cervical mucus, feces, and glands from different body regions stimulate the olfactory and oral systems, which, added to the visual, auditory, and tactile systems, trigger a series of reproductive and endocrine changes (Traldi 2005).

The behaviors of sniffing the male and sniffing the urogenital region of the male were observed at similar frequencies in the different shifts of each season; in addition, these behaviors were seen most intensely during the rainy season on all shifts. As animals tend to group more extensively during the rainy season and are more physically close, females in estrus smell the male and the male's urogenital region more frequently to capture the pheromones released by the males. These behaviors occurred more frequently during the initial shifts when the animals showed more interest in the sexual act. As noted by Llewelyn et al (1993), goats showed greater interest in the breeder since the beginning of oestrus, remaining high for a period of $12 \mathrm{~h}$.

In both seasons, the tail swing was shown in more significant proportion in the first shifts, when the external signs of estrus became more evident. According to Llewelyn et al (1993), the tail sway is observed at the beginning of oestrus, evidenced by the tendency to remain immobile to be covered. This behavior was observed mainly during the dry season in all shifts, representing an essential behavioral response that can be used to identify females in oestrus (Ola and Ebbunike, 2004).

Females had a higher frequency of tail lift on curve 5 of the rainy season. On the other hand, this tail elevation was observed less frequently during shift 1 of the same season; this may have been because the male's libido was higher during the initial shifts, resulting in less courtship, more mating, and less need for these behavioral responses. The adoption of behaviors such as raising the tail by females serves to facilitate and/or allow penile penetration (Ferraz 2011).

The frequency of urination differed between shifts, with increased activity during shift 5 of the rainy season and shift 3 of the dry season. These increases are mainly associated with the behavior of the male promoted by the male effect since the females stimulated by the breeders urinated more frequently. However, the signs presented by sheep in estrus are very discreet; as Nogueira et al (2011), among the signs that females show, there is frequent urination, especially if the male is courting or if the females are stimulated. Urination occurred less frequently during the last shift of the dry season, probably due to less water intake. It is noted that when exposed to high temperatures, animals adapted to tropical regions tend to have less water intake and are more efficient in the use of water, consequently, produce less urine (De Araújo et al 2011). 


\section{Conclusions}

The most frequently observed sexual behaviors of the female Morada Nova sheep in estrus grazed on the Caatinga consisted of turning the head searching for the male, tail lifting, and tail swinging. Morada Nova sheep reduce their water intake and grazing time to engage more efficiently in reproductive activities, thus demonstrating an ability to adapt to the Caatinga. Sheep females exteriorize sexual behavior patterns intensively during the rainy season.

\section{Acknowledgments}

The authors thank the support of the Study Group on Bioclimatology, Behavior, and Animal Welfare (BIOET) at the Federal University of Paraiba, Brazil.

\section{Conflict of Interest}

The authors declare that there is no conflict of interest with this work.

\section{Funding}

We are grateful for the financial support (scholarships) granted by the National Council for Scientific and Technological Development (CNPq) and Coordination for the Improvement of Higher Education Personnel (Capes), Brazil.

\section{References}

Aké-Villanueva JR, Aké-López JR, Magaña-Monforte JG, Segura-Correa, JC (2019) Reproductive behavior in hair sheep rams under tropical conditions. Tropical Animal Health Production 51:1627-1635.

Barbosa OR, Da Silva RG (1995) Índice de conforto térmico para ovinos. Boletim de Indústria Animal 52:29-35.

Beach FA (1976) Sexual attractivity, proceptivity, and receptivity in female mammals. Hormones and Behavior 7:105-138.

Buffington DE, Collazo-Arocho A, Canton GH, Pitt D, Thatcher WW, Collier RJ (1981) Black-globe-humidity index (BGHI as comfort equation for dairy cows). Transacton of the ASAE 24:711-714.

Campos FS, Gois GC, Vicente SLA, Macedo AD, Matias ADS (2017) Alternativa de forragem para caprinos e ovinos criados no semiárido. NutriTime 14:5004-5013.

Vianna E (2007) Comportamento e eficiência reprodutiva. Revista Brasileira de Reprodução Animal 31:177-182.

Côté SD Festa-Bianchet M (2001) Reproductive success in female mountain goats: the influence of age and social rank. Animal Behaviour 62:173-181.

De Araujo GGL, Voltolini T, Turco S (2011) A água nos sistema de produção de caprinos e ovinos. Embrapa Semiárido -ALICE.

De Sousa RT, Gonçalves JDL, Fonteles NDO, Dos Santos CM, Dela Ricci G, Albuquerque FD, Bomfim MAD (2015) Características reprodutivas de ovelhas Morada Nova e Somalis Brasileira. Embrapa Caprinos e Ovinos ALICE.

Ferraz MR (2011) Manual do comportamento animal. Rubio, Rio de Janeiro.
Fonsêca VF, Saraiva EP, Arruda MF, Pereira WE, Pimenta Filho EC, Santos SG, Silva JA (2016) Mother-offspring relationship in Morada Nova sheep bred in a tropical semiarid environment: A perspective on maternal investment and parental conflict. Applied Animal Behavior Science 183:51-58.

Gill W (2008) Applied sheep behavior. Agricultural Extension Service. Available:

http://animalscience.ag.utk.edu/sheep/pdf/appliedsheepbehavior-wwg-2 04.pdf. Accessed 18 March 2020.

Gomes WR, Butler WR, Johnson AD (1971) Effect of elevated ambient temperature on testis a blood levels and in vitro biosynthesis of testosterone in the rams. Journal Animal Science 3:804-807.

Köppen W (1936) Das Geographische system der Klimatologie. Berlim, Borntrager.

Llewelyn CA, Perrie J, Luckins AG (1993) Oestrus in the British white goat: timing of plasma luteinizing hormone surge and changes in behavioural and vaginal traits in relationship to onset of oestrus. British Veterinary Journal 149:171-182.

Martin GB, Hötzel MJ, Blache D, Walkden-Brown SW, Blackberry MA, Boukhliq R, Miller DW (2002) Determinants of the annual pattern of reproduction in mature male Merino and Suffolk sheep: modification of responses to photoperiod by an annual cycle in food supply. Reproduction Fertility Development14:165-175.

National Research Council (1985) Nutrients Requirements of Sheep. NRC, Washington, DC.

Nogueira DM, Eloy A, De Sá CO , Lopes Júnior ES, Figueiredo HOS, Sá JL, Sousa PHF (2011) Manejo reprodutivo.Embrapa Semiárido-Artigo em anais de congresso (ALICE). Petrolina: Embrapa Semiárido.

Ola SI, Egbunike GN (2004) Behavioural and morphological attributes of oestrus in West African dwarf does under different physiological states. Livestock Research Rural Development 16:10-15.

Pacheco A, Quirino CR (2010) Comportamento em ovinos.Revista Brasileira de Produção Animal 34:87-97

Pereira CCJ (2005) Fundamentos de Bioclimatologia Aplicados à Produção Animal. FEPMVZ, Belo Horizonte.

Roll VFB, Rech CDS, Xavier EG, Rech JL, Rutz F, Del Pino, FAB (2006) Comportamento animal: conceitos e técnicas de estudo. UFPel, Pelotas.

Rosa HJD, Bryant MJ (2002) The "ram effect" as a way of modifying the reproductive activity in the ewe. Small Ruminant Research 45:1-16.

Santos SGCGD, Saraiva EP, Pimenta EC, Santos LDFDD, Fonsêca VFC, Veríssimo TNS, Pinheiro ADC (2015) Seasonal and circadian variation of the sexual behavior of Morada Nova rams in tropical environment. Revista Brasileira de Zootecnia 44:8-14.

Saumand J, Rouger V (1972) Variations saisonniere de tax d'androgeneses dans le plasma du sang peripherique. CR Academic Science 274:89-92.

Sejian V, Maurya VP, Kumar K, Naqvi SMK(2012) Effect of multiple stresses (thermal, nutritional, and walking stress) on the reproductive performance of Malpura ewes. Journal Veterinary Medicine Science 2012:471760.

Stellflug JN, Lewis GS (2007) Effect of early and late exposure to estrual ewes on ram sexual performance classifications. Animal Reprodution Scence 97:295-302.

Traldi AS (2005) Manejo da reprodução em caprinos: Situação atual e perspectivas. Espírito Santo do Pinhal.

Villarroel ABS, Fernandes AAO (2000) Reproductive performance of Morada Nova Tropical hair sheep in Ceara state, Brazil. Revista Brasileira de Saúde e Produção Animal. 